ELORE (ISSN 1456-3010), vol. 19 - 1/2012.

Julkaisija: Suomen Kansantietouden Tutkijain Seura ry.

[http://www.elore.fi/arkisto/1_12/salmi-niklander.pdf]

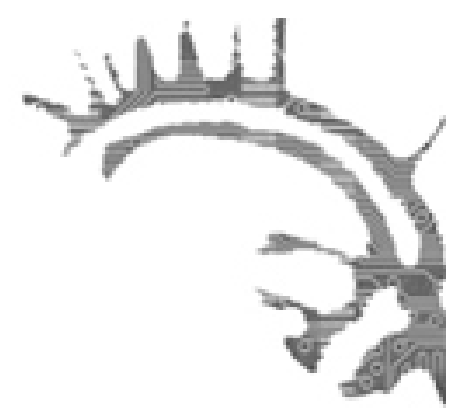

KatSAUS

\title{
TUTKIJAN VAELTAVA KATSE MENNEISYYDEN VIERAASSA MAASSA
}

\author{
$\underline{\text { Kirsti Salmi-Niklander }}$
}

OLLILA, ANNE 2010: Kirjoituksia kulttuurista, sukupuolesta ja historiasta. Historiallinen arkisto 132. Helsinki: SKS. 240 sivua.

RANTALA, HELI \& OLLITERVO, SAKARI (toim.) 2010: Kulttuuribistoriallinen katse. Turku: Kulttuurihistoria, Turun yliopisto. 404 sivua.

JOHNSON, BRUCE \& KIISKINEN, HARRI (toim.) 2010: They Do Things Differently There. Essays on Cultural History. Turku: Cultural History, University of Turku. 242 sivua.

Suomalainen kulttuurihistoria on pieni mutta aktiivinen tieteenala. Alan oppituolit sijaitsevat Turun ja Rovaniemen yliopistoissa, mutta myös monet muiden yliopistojen historiantutkijoista jakavat kulttuurihistorioitsijoiden kanssa herkkyyden erilaisille historiallisille lähteille ja niiden uusille tulkitsemistavoille. Kulttuurihistorian piirissä on syntynyt monia tutkimushankkeita ja kansainvälinen verkostoituminen on vilkasta. Esimerkiksi Turun kulttuurihistoria koordinoi kansainvälistä populaarikulttuurin tutkimusyksikköä (IIPC) ja järjesti kulttuurihistorioitsijoiden kansainvälisen seuran ISCH:n ensimmäisen konferenssin toukokuussa 2010.

Kulttuurihistorioitsijoiden ahkerasta julkaisutoiminnasta yhtenä konkreettisena osoituksena on kolme vuonna 2010 ilmestynyttä kirjaa: professori Anne Ollilan esseekokoelma sekä laitoksen julkaisusarjassa ilmestyneet artikkelikokoelmat. Suomen- ja englanninkielisissä teoksissa on osittain samoja artikkeleita. Toinen englanninkielisen julkaisun toimittajista on Turun yliopiston kulttuurihistorian vieraileva professori Bruce Johnson, joka on erikoistunut populaarimusiikin historian tutkimukseen. 
Kulttuurihistoria ja kulttuurien tutkimus (folkloristiikka, kansatiede ja antropologia) kohtaavat toisensa monissa tutkimusaiheissa ja metodologisissa kysymyksissä. Yhteisiä innoittajia ja haastajia ovat mikrohistoria ja mentaliteettihistoria, joiden suuria nimiä ovat Carlo Ginzburg, Giovanni Levi ja Natalie Zemon Davis. Historiantutkijat ovat löytäneet kulttuurien tutkimuksesta välineitä erityisesti tapojen, rituaalien ja symbolien analysoimiseen. Clifford Geertz on vaikuttanut mentaliteetti- ja mikrohistorian metodologiseen kehitykseen näkemyksillään jaetuista kulttuurisista symboleista sekä tapahtumien ja tilanteiden diagnostisesta analyysista. Historiantutkija ja antropologi tutkivat molemmat niin sanotusti vierasta maata, joka historiantutkijoille löytyy menneisyyden fragmentaarisista ja aukkoisista lähteistä, antropologeille taas vieraista kulttuureista. Folkloristien ja kansatieteilijöiden vieras maa voi löytyä joko menneisyydestä tai elävistä ja muotoutumassa olevista nykykulttuurin ilmiöissä. Sekä historian että kulttuurien tutkijat rakentavat geertziläistä tiheää kuvausta (thick description) analysoiden arkisten tilanteiden ja kohtaamisten merkityskerrostumia ja niiden välisiä ristiriitoja.

Mistä löytyvät ne tekijät, jotka edelleen erottavat kulttuurihistoriaa ja kulttuurien tutkimusta? Mitä opittavaa näillä tieteenaloilla on toisiltaan? Etsin arvioitavista kirjoita vastauksia näihin kysymyksiin ryhtymättä käymään yksityiskohtaisesti läpi teosten sisältöä.

\section{TYYPILLISYYS JA TOTUUDEN ETSINTÄ}

Heli Rantala kartoittaa artikkelissaan suomalaisen kulttuurihistorian yllättävän kauas ulottuvia juuria. Gunnar Suolahden merkitys varhaisen kulttuurihistoriallisen koulukunnan luojana on nostettu esille jo aiemmassa tutkimuksessa. J. V. Snellman suhtautui 1840-luvun kirjoituksissaan kriittisesti "suurmieshistoriaan" ja tervehti ilolla merkkejä uudenlaisesta historiantutkimuksesta, joka kuvaisi myös "suurten joukkojen tapoja ja niiden älyllisten pyrintöjen tasoa sekä vallitsevaa uskonnollista henkeä".

Anne Ollila käsittelee kirjassaan kulttuurihistorian piirissä käytyä tuoretta keskustelua, joka kytkeytyy mikrohistoriaan, antropologiaan ja sukupuolentutkimukseen. Yksilön ja yhteisön suhde historiallisissa tulkinnoissa on yksi keskeisistä kysymyksistä mikrohistorian piirissä käydyssä kriittisessä keskustelussa. Voidaanko menneen ajan ihmistä tarkastella yksilönä vai ainoastaan oman sosiaaliryhmänsä edustajana?

Ollila kommentoi Simona Ceruttin tuoretta artikkelia, jossa tämä hahmottaa mikrohistorian suuntauksia suhteessa historiallisen tiedon kontekstualisointiin. Sosiaalisen kontekstualisoinnin tunnetuin edustaja on Giovanni Levi, joka tarkastelee tutkittavia henkilöitä oman sosiaaliryhmänsä edustajana. Levi määrittelee yhteiskunnan sosiaaliset rakenteet tärkeimmäksi vaikuttavaksi tekijäksi yksilöiden toiminnan taustalla. Carlo Ginzburg puolestaan kiinnittää huomion tutkimuskohteensa (kuuluisampana esimerkkinä mylläri Menocchio, Juusto ja madot -teoksen päähenkilö) omiin tulkintoihin ja siihen, miten nämä tulkinnat on rakennettu erilaisista suullisen ja kirjallisen kulttuurin aineksista. Ginzburgia on arvosteltu siitä, ettei hän kiinnitä huomiota Menocchion ja hänen ajatusmaailmansa tyypillisyyteen tai epätyypillisyyteen. Sosiaalisen kontekstualisoinnin edustajat hyödyntävät strategian käsitettä metodologisena työkaluna: tutkijat käsittelevät tutkimuskohteitaan rationaalisina toimijoina sijoittaen heidät 
aikansa sosiaalisiin rakenteisiin. Cerutti kuitenkin arvostelee tätä lähestymistapaa, joka perustuu suurelta osin tutkijoiden konstruoimille historian rakenteille. Kulttuurihistorian tuoreimmissa suuntauksissa onkin ryhdytty korostamaan rakennehistoriallisten tulkintojen sijaan sosiaalisia käytäntöjä.

Kulttuurien tutkijat tarkastelevat menneisyyden ihmisiä ja heidän tuottamiaan lähteitä ennen kaikkea kulttuurisissa konteksteissa. Yksilölliset tulkinnat suhteutetaan sosiaalisten rakenteiden sijasta kollektiivitraditioon ja kansanomaiseen ajatteluun. Simona Cerutti on etsinyt antropologiasta tutun emic-näkökulman avulla yksilöiden omia termejä ja tulkintoja. Yhteisön ja yksilön suhde on dynaaminen vuorovaikutusprosessi, jossa alistaminen ja vastarinta, kilpailu ja kumppanuus vuorottelevat. Ristiriidat ja jännitteet ovat tärkeitä tutkimuksen ja havainnoinnin kohteita, "jotta menneisyyttä ei tulkittaisi liian ehjäksi, pysähtyneeksi tai harmoniseksi”.

\section{Mitä TAPAHTUI TODELla?}

Keskusteluissa historiantutkijoiden kanssa tulevat ennemmin tai myöhemmin esille kysymykset, jotka erottavat folkloristiikan ja historiantutkimuksen näkökulmat: Onko tämä todella tapahtunut? Onko tämä tieto tai kertomus luotettava todiste siitä? Folkloristit ovat pyrkineet ehkä liiankin pitkälle välttämään kysymystä tapahtumien totuudesta. Kiteytynyt suullinen perinne (tai se osa siitä, joka on talletettu arkistoihin) käsittelee suurelta osin fiktiivisiä tapahtumia, joiden kohdalla kysymys totuudesta on epärelevantti. Myös fiktiivinen suullinen perinne voi heijastaa sosiaalihistoriallisia murroksia, kuten Satu Apo on todennut satututkimuksissaan. Historiallisten tarinoiden ja muistitiedon kohdalla myös kertojat ottavat kantaa kertomusten ja todellisten historiallisten tapahtumien suhteisiin.

Naishistorian ja muiden niin sanottujen uusien historioiden tavoitteena on Anne Ollilan mukaan historian suuren kertomuksen purkaminen ja uudelleen kirjoittaminen. Samalla myös totuusarvon määrittelyä arvioidaan uudelleen: totuus ei enää tarkoita loogista ja ristiriidatonta kertomusta, vaan vaihtoehtoiset tulkinnat nostetaan tutkimuksen ja analyysin kohteeksi.

Kulttuurihistorioitsijat ovat pohtineet myös mahdollisen ja imaginaarisen suhdetta. "Menneisyyden maailmassa voitiin kuvitella mahdottomia ja nämä mahdottomat mahdollisuudet olivat itsessään tosia menneisyyden ilmiöitä”, toteaa Hannu Salmi Kulttuuribistoriallinen katse -teoksen päätösartikkelissa. Mahdollisen historia liittyy myös siihen, millaisia päätelmiä voidaan tehdä hyvin niukan ja fragmentaarisen lähdeaineiston pohjalta. Mahdollisen historiaa on myös kutsuttu virtuaaliseksi historiaksi, joka nousee esille erityisesti silloin, kun tietoisesti kohdistetaan katse marginaaleihin: sellaisiin ihmisiin ja yhteisöihin, joista on säilynyt hyvin niukasti lähdeaineistoa. Tähän keskusteluun folkloristeilla olisi paljon annettavaa, sillä perinneaineistot käsittelevät usein juuri mahdottomia mahdollisuuksia. 


\section{KIELESTÄ KÄYTÄNTÖIHIN}

1980-luvulta lähtien historiantutkimuksen kielellinen käänne on vahvistanut kytköksiä historiantutkimuksen, folkloristiikan ja kirjallisuudentutkimuksen välillä. Kulttuurihistorioitsijat tutkivat erilaisia puhetapoja, representaatioita ja tiedon tuottamisen muotoja. Diskurssianalyysi oli etenkin 1990-luvulla suosittu metodinen väline näiden puhetapojen hahmottamisessa.

Käytäntö on 2000-luvulla noussut yhä keskeisemmäksi käsitteeksi kulttuurihistorian piirissä. Riitta Laitinen toteaa Kulttuuribistoriallinen katse-teoksen artikkelissaan, että vaikkei tämä käsite esiinny selkeästi määriteltynä tutkimusten johdantoluvuissa, siitä on kuitenkin tullut tärkeä työväline. Sosiaalitieteistä omaksuttu käytäntöteoria haastaa teoriat, joka tulkitsevat ihmisten toimintaa kielen ja representaatioiden kautta. Käytäntö toteutuu ruumiillistuneessa toiminnassa, mutta se kytkeytyy myös niin sanottuun hiljaiseen tietoon.

Olen havainnut käytäntö-sanan yleistymisen ja käyttökelpoisuuden omalla tutkimusalueellani, jonka voisi määritellä kirjallistumisen (literacy) tutkimukseksi. Kirjallistumisen käytäntöjen ja prosessien monitieteinen tutkimus on kansainvälisesti kiinnostusta herättävä ala. Käytäntö (practice) -termi on tullut tunnetuksi kirjallistumista sekä suullisen ja kirjallisen kulttuurin vuorovaikutusta käsittelevien antropologisten ja käyttäytymistieteellisten tutkimusten kautta (esim. David Barton, Niko Besnier, Brian Street). Sen avulla suullinen ja kirjallinen kulttuuri voidaan kytkeä arkiseen toimintaan ja vuorovaikutukseen.

\section{Herrat ja Rahvas}

Yksi kulttuurihistoriaa ja kulttuurien tutkimusta selkeästi erottava piirre on se, että kulttuurien tutkimuksen kohteena on edelleen "kansa", vaikka tämän termin määrittely on osoittautunut ongelmalliseksi sekä historiassa että nykypäivässä. Vielä ongelmallisemmaksi määrittely osoittautuu, jos kansaa tai kansanihmisiä ryhdytään kääntämään muille kielille, erityisesti englanniksi.

Monet kulttuurihistorioitsijat ovat suunnanneet tutkimuksensa kansanihmisiin ja yhteiskunnan marginaaleihin. Kansainvälisen tutkimuksen kuuluisia tapauksia ovat Menocchion lisäksi Natalie Zemon Davisin tutkima 1500-luvun ranskalainen talonpoika Martin Guerre. Hyvä esimerkki suomalaisen kulttuurihistorian piiristä on Pälvi Rantalan tutkima "Kalkkimaan pappi", Alatorniolla 1800-luvulla elänyt Pietari Herajärvi. Hän tuli tunnetuksi esittämällä omat versionsa pappien saarnoista kirkonmenojen jälkeen. Pälvi Rantala erittelee artikkelissaan "Kalkkimaan papista" esitettyjä tulkintoja ja myyttien rakentamista.

Toisaalta monet kulttuurihistorioitsijat suuntaavat katseensa ylempiin yhteiskuntaluokkiin siitä syystä, että nämä ovat tuottaneet runsaasti rikkaita lähteitä, joissa pohditaan tunteisiin ja ruumiillisuuteen liittyviä kysymyksiä. Tästä ovat esimerkkeinä Marjo Kaartisen tutkimus rintasyöpään liittyvien kulttuuristen käsitysten historiasta sekä Kirsi Tuohelan tutkimus melankolian historiasta. Myös Ritva Hapulin ja Maarit 
Leskelä-Kärjen artikkeli kirjoittamisen kulttuurihistoriasta painottuu sivistyneistökirjoittajiin, vaikka kulttuurihistorioitsijoista esimerkiksi Kaisa Vehkalahti on tutkinut myös koulukotityttöjen kirjoittamista.

Näkökulmien yhdistäminen ja risteyttäminen voisi olla hedelmällinen lähtökohta tutkittaessa kansankulttuurin ja hegemonisen kulttuurin välisiä rajoja ja vuorovaikutusta. Missä määrin keski- ja yläluokan tuottamien lähteiden pohjalta voidaan tehdä yleistyksiä ajan ajattelu- ja kokemistavoista? Mikä on se mentaalinen ydin, joka yhdistää herroja ja rahvasta?

\section{ULOS KELTAISESTA SUKELLUSVENEESTÄ?}

Kulttuurihistoria ja kulttuurintutkimus (cultural studies) kytkeytyvät toisiinsa erityisesti populaarikulttuurin tutkimuksessa. Kimi Kärki ja Kari Kallioniemi pohtivat tätä artikkelissaan, joka on julkaistu sekä suomen- että englanninkielisessä kokoelmassa. Kulttuurihistorioitsijalle "kulttuuri" on avain historian uusiin tulkintoihin. Kulttuurintutkijalle se on metateoreettinen väline. Kärki ja Kallioniemi erittelevät kiinnostavasti ala- ja vastakulttuurien sekä työväenkulttuurin tutkimuksen erilaisia juonteita brittiläisessä kulttuurintutkimuksen traditiossa. Tämä keskustelu olisi kiinnostavaa suhteuttaa myös suomalaiseen keskusteluun, jossa kansankulttuuri ja talonpoikaiskulttuuri ovat olleet yhtä lailla jännitteisiä, romantisoituja ja torjuttuja termejä kuin brittiläinen työväenkulttuurikin.

Tein tämän vuoden alussa kiinnostavia havaintoja tuoreesta brittiläisestä kulttuurintutkimuksesta ja kulttuuriperinnön hyödyntämisestä Englannin-matkalla, jonka aikana vierailin muun muassa työväenkulttuurin ja populaarimusiikin kehdossa, Liverpoolissa. Kärki ja Kallioniemi lainaavat artikkelissaan Stuart Hallia, joka nostaa Beatles-laulusta tutun keltaisen sukellusveneen uusliberalismin symboliksi. Liverpoolissa on koettavissa todellinen keltainen sukellusvene, amfibio-turistibussi, joka kulkee sekä maalla että vedessä. Se on yksi esimerkki siitä, miten rappeutuneen teollisuuskaupungin "kultaista menneisyyttä" on rakennettu populaarimusiikin pohjalle. Mutta onko siitä tulevaisuuden rakennusaineeksi? Menneisyyden ja tulevaisuuden visioita esitellään upeasti Liverpoolin museossa, josta on tullut todellinen kansalaisten olohuone. Tein matkalla myös sellaisen kiinnostavan havainnon, että peasant poet (suom. rahvaanrunoilija) John Clare (1793-1864) on kokenut renessanssin viime vuosikymmeninä, vaikka hän on varsin tuntematon anglosaksisen maailman ulkopuolella. Työväenkulttuurin ja -kirjallisuuden tutkimus näyttää myös Brittein saarilla elävän uutta nousukautta.

Tätä arviota kirjoittaessani olin juuri osallistunut "Tuumasta toimeen"-keskustelutilaisuuteen, jossa perustettiin kulttuuriosaamo Toimi. Kulttuurien tutkijoiden kannattaa ottaa esimerkkiä kulttuurihistorioitsijoiden aktiivisesta kansainvälisestä verkostoitumisesta ja suunnitella myös yhteisiä hankkeita. Kulttuuri ei ole ylellisyyttä, vaan se on elinehto tulevaisuuden rakentamiselle!

\section{Kirsti Salmi-Niklander on folkloristiikan dosentti ja akatemiatutkija Helsingin yliopistossa.}

